Article

\title{
CTAB modification of MCM-49 zeolite containing HMI and its acylation of anisole
}

\author{
Huijuan Wei a,b, Sujuan Xie a, Kefeng Liu a,c, Wenjie Xin a, Xiujie Li a, Shanhe Liu d, Shunming Gu d, \\ Shenglin Liu a, Longya Xu a,* \\ a Dalian Institute of Chemical Physics, Chinese Academy of Sciences, Dalian 116023, Liaoning, China \\ b University of Chinese Academy of Sciences, Beijing 100049, China \\ c Petrochemical Research Institute of PetroChina Company Limited, Beijing 100029, China \\ dAnhui Costar Biochemical Co. Ltd., Dangtu 243100, Anhui, China
}

A R T I C L E I N F O

Article history:

Received 5 April 2015

Accepted 5 May 2015

Published 20 October 2015

Keywords:

MCM-49 zeolite

Template

Post-treatment

CTAB

Acylation

\begin{abstract}
A B S T R A C T
A series of MCM-49 zeolite catalysts containing different amounts of the hexamethyleneimine (HMI) template were calcined at different temperatures, and then modified with cetyltrimethylammonium bromide (CTAB). Changes in structural and acidic properties were investigated by XRD, $\mathrm{N}_{2}$ adsorption, $\mathrm{NH}_{3}$-TPD, adsorbed pyridine infrared and DRIFTS measurements, and ${ }^{29} \mathrm{Si}$ and ${ }^{27} \mathrm{Al}$ MAS NMR. There were cleaning off of amorphous particles and extraframework $\mathrm{Al}$ atoms inserted into the framework of the zeolite due to the CTAB modification. These two effects resulted in more framework $\mathrm{Al}$ in the CTAB modified samples than the untreated samples, and a higher Brönsted acid concentration, which was confirmed by the acylation of anisole with acetic anhydride. The catalytic roles of the acid sites located in the different pore systems in the zeolite were investigated. It was verified that the active sites after CTAB modification were mainly in the HMI-free regions.
\end{abstract}

(C) 2015, Dalian Institute of Chemical Physics, Chinese Academy of Sciences. Published by Elsevier B.V. All rights reserved.

\section{Introduction}

Friedel-Crafts acylation of aromatics is an important reaction for manufacturing aromatic ketones, which are key intermediates in many chemical industrial processes for the production of fine chemicals, agrochemicals, pharmaceuticals and fragrances [1-5]. The traditional catalysts, such as $\mathrm{AlCl}_{3}$ and $\mathrm{H}_{2} \mathrm{SO}_{4}$, have limitations when used in Friedel-Crafts acylation because of environmental pollution, reactor corrosion and product isolation, so replacing the traditional catalysts with a zeolite has attracted research interest and attention [2-8]. An MWW zeolite showed interesting activity for the acetylation of aromatics due to the acid sites located on its external surface and it exhibited good resistance to deactivation [6]. Many re- searchers have paid attention to Friedel-Crafts acylation using MWW zeolite catalysts.

The micropores in the MWW zeolite lead to diffusion limitation for the transport of reactant molecules to the active sites, especially in reactions involving big molecules, which severely restricts its catalytic application. The post-treatment of an MWW zeolite to improve its catalytic performance has been extensively studied, and desilication by an alkali treatment has received attention because it is easy to manipulate $[9,10]$. However, there is a conflict between preserving acidity and the creation of extra porosity, and desilication and re-assembly of dissolved species can occur when treating the zeolite with alkali in the presence of a long chain alkylammonium surfactant, such as cetyltrimethylammonium bromide (CTAB) [9,11-14].

\footnotetext{
* Corresponding author. Tel/Fax: +86-411-84379279; E-mail: lyxu@dicp.ac.cn 
Xu's group [15-18] have studied the alkali treatment of MWW zeolite with and without CTAB, and found that a mild alkali treatment can clean off amorphous particles on the MCM-49 crystal surface, but a severe alkali treatment would result in significant destruction of the zeolite structure and introduce extra mesopores regardless of whether there was CTAB in the $\mathrm{NaOH}$ solution.

In addition, CTAB can be applied as an additive to the alkaline solution in the preparation of hierarchical zeolites by desilication. CTAB was previously used for the swelling of MWW layered zeolite precursors in the presence of a base followed by delamination. Corma et al. $[19,20]$ investigated the delamination of a layered MCM-22(P) (precursor of MCM-22 zeolite) by swelling it with $\mathrm{CTAB}$ and tetrapropylammonium hydroxide (TPAOH), followed successively by various treatments with an ultrasound bath, hydrochloric acid and calcination. They found that the material obtained (ITQ-2) exhibited better activity than MCM-22 for vacuum gasoil cracking. Many research works [21-24] were carried out to produce MCM-36 zeolite by swelling $\mathrm{MCM}-22(\mathrm{P})$ with cetyltrimethyl ammonium cations $\left(\mathrm{CTA}^{+}\right)$ in the presence of a base (e.g. TPAOH), and then pillaring it with tetraethoxysilane (TEOS) derived silica.

Our group has investigated $\mathrm{NaOH}$ and $\mathrm{CTAB}$ co-modification of MCM-49 zeolite with different hexamethyleneimine (HMI) template contents, and found that $\mathrm{NaOH}$ can destroy the framework of the zeolite by attacking the HMI-free regions, and that the dissolved species can be transformed into OMMs by the directing of CTAB micelles [15]. We have also studied the alkali treatment of MCM-49 zeolite in the presence of different surfactants, such as dodecyltrimethyl ammonium bromide, tetradecyltrimethyl ammonium bromide and octadecyltrimethyl ammonium bromide, and found that the samples modified with $\mathrm{NaOH}$ and different surfactants showed similar textural properties and acidity. Thus we can ask about what would happen if only the surfactant, e.g., CTAB, was used to modify MCM-49, which is a 3D zeolite. Based on this background, in this work, a detailed study of the partial de-templating of MCM-49 zeolite by calcination followed by CTAB modification was carried out. The materials were characterized by many techniques, including XRD, $\mathrm{N}_{2}$ adsorption, $\mathrm{NH}_{3}$-TPD, Py-IR and DRIFTS, and ${ }^{29} \mathrm{Si}$ and ${ }^{27} \mathrm{Al}$ MAS NMR. Their catalytic activity in the acylation of anisole (AN) with acetic anhydride (AA) was studied to shed light on the nature of the acid sites involved in the reaction.

\section{Experimental}

\subsection{Catalyst preparation}

The MCM-49 zeolite (supplied by Tieling Deshijie Chemical Limited Company, molar ratio of $\mathrm{Si} / \mathrm{Al}=11.0$ ) containing the HMI template, labelled as MCM-49S, was calcined at $550{ }^{\circ} \mathrm{C}$ for $4 \mathrm{~h}$, and transformed into the $\mathrm{H}$ form (named as HMCM-49) by ion exchange [25]. MCM-49S was calcined at different temperatures $\left(250,350,450\right.$ or $\left.550{ }^{\circ} \mathrm{C}\right)$ for $4 \mathrm{~h}$ (labelled as $\mathrm{CT}, \mathrm{T}$ was the calcination temperature), then treated in CTAB solution $(0.27 \mathrm{~mol} / \mathrm{L})$ with the desired amount of $10 \mathrm{~mL} / \mathrm{g}$ at $70{ }^{\circ} \mathrm{C}$ for 1
$\mathrm{h}(\mathrm{pH}=5-7)$. It was then cooled down to room temperature in a cold bath. The solid product was recovered by centrifugal separation, dried at $110{ }^{\circ} \mathrm{C}$ overnight and calcined at $550{ }^{\circ} \mathrm{C}$ for $4 \mathrm{~h}$. The $\mathrm{H}$ form products (denoted as HMCM-T-CTAB) were obtained by ion exchange. The sample obtained by treating MCM-49S with CTAB solution directly was named as HMCM-S-CTAB.

Samples with pre-coked supercages were prepared by $m$-xylene reaction according to the procedure reported in Ref. [26-28] and were denoted as Z-xy (Z: HMCM-49, HMCM-T-CTAB or HMCM-S-CTAB). All Z materials were first pretreated at $500{ }^{\circ} \mathrm{C}$ for $1 \mathrm{~h}$ with a $\mathrm{N}_{2}$ flow and cooled to $350{ }^{\circ} \mathrm{C}$. Then, $m$-xylene was pumped into the reactor, and the reaction conditions were set as: atmospheric pressure, $350{ }^{\circ} \mathrm{C}, \mathrm{m}$-xylene weight hourly space velocity (WHSV) of $13 \mathrm{~h}^{-1}$ with $\mathrm{N}_{2}$ flow rate of $32.5 \mathrm{~mL} / \mathrm{min}$, and time on stream of $10 \mathrm{~h}$. Samples with only sinusoidal pores accessible, named as Z-xy-DMQ, were prepared by poisoning the external surface of Z-xy by 2,4-dimethylquinoline (2,4-DMQ) adsorption. All the samples were crushed and sieved into $0.38-0.85 \mathrm{~mm}$ particles for further use.

\subsection{Catalyst characterization}

$\mathrm{N}_{2}$ adsorption isotherms were measured at $-196{ }^{\circ} \mathrm{C}$ with a Micromeritics ASAP-2020 apparatus. Prior to the measurement, the fresh sample was degassed at $350{ }^{\circ} \mathrm{C}$ under a vacuum of $1 \mathrm{mPa}$ for $10 \mathrm{~h}$. The pre-coked samples were pretreated only at $100{ }^{\circ} \mathrm{C}$ for $2 \mathrm{~h}$ to prevent the coke from being removed. The BET equation was used to calculate the surface area and the micropore volume was estimated by the $t$-plot method.

X-ray diffraction (XRD) patterns were collected on an X' Pert PRO X-ray diffractometer operated at $40 \mathrm{kV}$ and $40 \mathrm{~mA}$ using $\mathrm{Cu} K_{\alpha}$ radiation. The relative crystallinity (RC) was estimated by comparing the sum of the peak heights of $2 \theta=10.0^{\circ}, 14.3^{\circ}$, $16.0^{\circ}, 22.7^{\circ}$ and $26.0^{\circ}$ of the sample with that of HMCM-350-CTAB whose RC was assumed as $100 \%$. The chemical compositions of the samples were analyzed on a Philip Magix 601X X-ray fluorescene (XRF) spectrometer.

${ }^{29} \mathrm{Si}$ MAS NMR experiments were carried out on a Bruker DRX-400 spectrometer using $4 \mathrm{~mm} \mathrm{ZrO}_{2}$ rotors. The spectra were recorded at $99.4 \mathrm{MHz}$ with the magic angle spinning rate of $5 \mathrm{kHz} .{ }^{27} \mathrm{Al}$ MAS NMR spectra were recorded at $104.2 \mathrm{MHz}$ using a $0.5 \mu$ s pulse with a 2 s recycle delay and 1024 scans.

$\mathrm{NH}_{3}$ temperature programmed desorption ( $\left.\mathrm{NH}_{3}-\mathrm{TPD}\right)$ was carried out with a U-shaped quartz microreactor (i.d. $=4 \mathrm{~mm}$ ) connected to an online gas chromatograph (Shimadzu GC-8A) equipped with a thermal conductivity detector (TCD). The TCD response was calibrated by doses containing known amounts of $\mathrm{NH}_{3}$. In a typical experiment, the sample (140 mg) was first pretreated at $600{ }^{\circ} \mathrm{C}$ for $0.5 \mathrm{~h}$ under a He flow rate of 25 $\mathrm{mL} / \mathrm{min}$ to remove adsorbed organic species and moisture, then cooled down to $150{ }^{\circ} \mathrm{C}$ and saturated with $\mathrm{NH}_{3}$. After a stable baseline was obtained, the sample was heated from 150 to $600{ }^{\circ} \mathrm{C}$ at a heating rate of $19.6{ }^{\circ} \mathrm{C} / \mathrm{min}$.

Brönsted and Lewis acid concentrations of the samples were determined by pyridine adsorption followed by infrared 
(Py-IR) measurement on a Vertex 70 IR spectrometer. The sample was pressed into a self-supported wafer (ca. $10 \mathrm{mg}$ ) followed by evacuation at $250{ }^{\circ} \mathrm{C}$ for $1 \mathrm{~h}$ in the IR cell. A spectrum was recorded as the background after the wafer has cooled down to room temperature. Subsequently, the wafer was exposed to pyridine vapour for $20 \mathrm{~min}$ at $0{ }^{\circ} \mathrm{C}$ and then outgassed at $150{ }^{\circ} \mathrm{C}$ for $30 \mathrm{~min}$. Finally, the Py-IR spectra of the sample were collected at room temperature.

Diffuse reflectance infrared Fourier transform spectroscopy (DRIFTS) was measured with a Thermo Nicolet Nexos 470 instrument (resolution $4 \mathrm{~cm}^{-1}$, integration over 20 scans) equipped with a Harrick diffuse reflectance attachment. The sample powder (30 mg) was placed in a DRIFT cell with a $\mathrm{KBr}$ window and pretreated in flowing dry $\mathrm{N}_{2}$ flow (> 99.99\%, 30 $\mathrm{mL} / \mathrm{min}$ ) at $350{ }^{\circ} \mathrm{C}$ for $30 \mathrm{~min}$. After the pretreatment, the sample was cooled, and IR spectra were acquired at $30^{\circ} \mathrm{C}$.

\subsection{Catalyst evaluation}

The acylation of AN with AA was carried out in a continuous flow stainless steel fixed bed reactor. In a typical run, $1 \mathrm{~g}$ of catalyst was loaded into the central part of the reactor and pretreated at $500{ }^{\circ} \mathrm{C}$ for $1 \mathrm{~h}$ with a flow of $\mathrm{N}_{2}$. Then, the catalyst was cooled down to $110{ }^{\circ} \mathrm{C}$ and the reactants were pumped into the reactor. The reaction conditions were set as: $1.0 \mathrm{MPa}$, $110{ }^{\circ} \mathrm{C}$, the weight hourly space velocity (WHSV) of $10.2 \mathrm{~h}^{-1}$ with an AN/AA molar ratio of 5 .

The catalysts Z-xy were washed with AN (300 mL/(h-g)) for $30 \mathrm{~min}$ to remove carbon on the surface of catalysts before the reactants were introduced. Z-Xy-DMQ was obtained by poisoning the external surface of Z-xy with 2,4-DMQ. When the acylation of AN with AA was carried out, some 2,4-DMQ (flow rate of $207 \mu \mathrm{mol} /(\mathrm{g} \cdot \mathrm{h})$ ) [26,28] was added into the reactant stream. The products were collected and analyzed by an Agilent 7890A gas chromatograph with a HP PONA column and FID detector.

\section{Results and discussion}

\subsection{CTAB modification of MCM-49S and CT samples}

\subsubsection{Effect of CTAB modification on the structural properties}

The thermogravimetric analysis and textural properties of MCM-49S and CT samples had been discussed in Section 3.1 of Ref. [15]. Then the samples were treated with CTAB 0.27 $\mathrm{mol} / \mathrm{L}$ ) at $70{ }^{\circ} \mathrm{C}$ for $1 \mathrm{~h}$, and transformed into the $\mathrm{H}$ form. It should be emphasized that no $\mathrm{Br}$ was detected on the samples

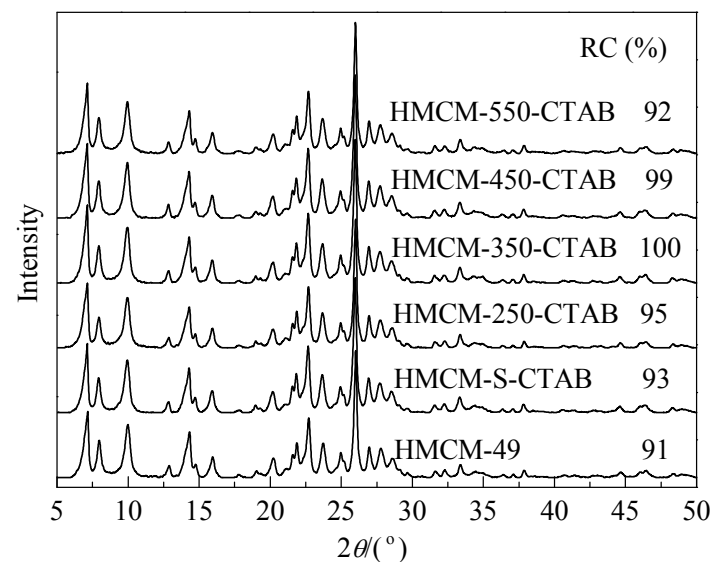

Fig. 1. XRD patterns of HMCM-49, HMCM-S-CTAB and HMCM- $T$-CTAB.

by XRF, showing that all CTAB species were fully ion exchanged. The yields of the whole process were in the range of $84 \%-89 \%$, as listed in Table 1 . Fig. 1 shows the XRD patterns of HMCM-49 and the partial de-templated samples after CTAB modification. All the samples after CTAB modification maintained the crystalline structure of MCM-49 zeolite [29], and their RCs remained in the range of $92 \%-100 \%$, showing that there was no framework destruction during the process of partial de-templation and CTAB modification under our experiment conditions. Furthermore, the RCs of the samples after CTAB modification, especially for HMCM-350-CTAB and HMCM-450-CTAB, were higher than that of HMCM-49, meaning that some amorphous particles were cleaned off from the zeolite during the modification, which is similar to what happened in the case of a mild alkali treatment [17].

Many works [21-23] have reported that treating MCM-22(P) with $\mathrm{CTA}^{+}$under a $\mathrm{pH}$ value as high as 13.8 would cause severe swelling. The relevant low angle XRD pattern of the swollen MCM-22(P) showed a reflection at $2 \theta \leq 2^{\circ}$. However, in our present case, no reflection was detected in the low angle XRD patterns of all the samples (data not given). Obviously, the unique characteristic of the process of CTAB modification is that no swelling of the treated material was involved.

The textural properties of HMCM-49 and the partially de-templated MCM-49 samples after CTAB modification are presented in Table 1. As shown, compared with HMCM-49, the BET surface area, external surface area, micropore volume, and total pore volume of all the samples after CTAB modification changed little, showing that no framework destruction hap-

Table 1

Textural properties of HMCM-49, HMCM-S-CTAB and HMCM-T-CTAB.

\begin{tabular}{lcccccccc}
\hline Sample & $\mathrm{Si} / \mathrm{Al}$ a & $\begin{array}{c}\text { Yield } \\
(\%)\end{array}$ & $\begin{array}{c}S_{\text {BET }} / \\
\left(\mathrm{m}^{2} / \mathrm{g}\right)\end{array}$ & $\begin{array}{c}S_{\text {micro }} / \\
\left(\mathrm{m}^{2} / \mathrm{g}\right)\end{array}$ & $\begin{array}{c}S_{\text {exter }} / \\
\left(\mathrm{m}^{2} / \mathrm{g}\right)\end{array}$ & $\begin{array}{c}V_{\text {total }} / \\
\left(\mathrm{cm}^{3} / \mathrm{g}\right)\end{array}$ & $\begin{array}{c}V_{\text {micro }} / \\
\left(\mathrm{cm}^{3} / \mathrm{g}\right)\end{array}$ & $\begin{array}{c}V_{\text {meso }} / \\
\left(\mathrm{cm}^{3} / \mathrm{g}\right)\end{array}$ \\
\hline HMCM-49 & 11.0 & & $492(192)$ & $374(117)$ & $118(75)$ & $0.52(0.35)$ & $0.17(0.05)$ & $0.35(0.30)$ \\
HMCM-S-CTAB & 11.5 & 84 & $491(189)$ & $380(115)$ & $111(74)$ & $0.50(0.35)$ & $0.17(0.05)$ & $0.33(0.30)$ \\
HMCM-250-CTAB & 11.6 & 89 & 509 & 389 & 120 & 0.56 & 0.18 & 0.38 \\
HMCM-350-CTAB & 11.8 & 88 & $502(197)$ & $384(122)$ & $118(75)$ & $0.51(0.36)$ & $0.17(0.05)$ & $0.34(0.31)$ \\
HMCM-450-CTAB & 11.7 & 86 & 521 & 411 & 110 & 0.53 & 0.19 & 0.34 \\
HMCM-550-CTAB & 11.4 & 84 & $502(189)$ & $391(113)$ & $111(76)$ & $0.51(0.34)$ & $0.18(0.05)$ & $0.33(0.29)$ \\
\hline
\end{tabular}

a $\mathrm{Si} / \mathrm{Al}$ molar ratio measured by XRF.

b Data in parentheses were the values of the corresponding pre-coked samples. 
pened during the modification process. In fact, the micropore surface areas of the samples after CTAB modification were higher than that of HMCM-49, implying that a small amount of amorphous particles were cleaned off from the zeolite, which was consistent with the conclusion from the XRD result. It is reasonable to postulate that no mesopores, either intracrystalline or intercrystalline mesopores, were introduced during the process of CTAB modification. Clearly, this is quite different from the situation of a severe alkali treatment [17,30,31].

Combining the results of Fig. 1 with Table 1, we deduced that there was no condensation of siliceous species, which would result in the formation of mesoporous fragments (e.g. MCM-41-type materials), in this process, although this was usually observed when the zeolite was treated with an alkaline solution in the presence of $\mathrm{CTA}^{+}[11,15,32-34]$. The Si/Al molar ratio of the samples after $\mathrm{CTAB}$ modification were in the range of 11.4-11.8, which was a little larger than that of HMCM-49 (11.0), implying that a small amount of amorphous $\mathrm{Al}$ on the MCM-49 crystal surface was cleaned off during the CTAB treatment process.

The textural properties of the corresponding pre-coked samples are listed in parenthesis in Table 1. After the HMCM-49 sample was pre-coked by $m$-xylene reaction, the micropore volume decreased by $29 \%$ (from 0.17 to $0.05 \mathrm{~cm}^{3} / \mathrm{g}$ ), which is in good agreement with the data reported in Ref. [26]. This suggested that the supercages were successfully blocked by the coke generated in the reaction while the sinusoidal channels were preserved. The external surface area was slightly de-

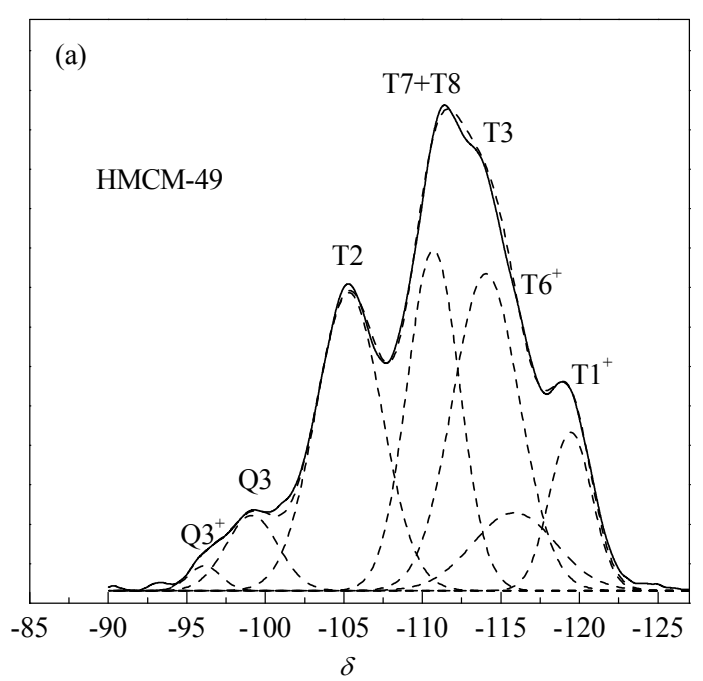

creased (from 118 to $75 \mathrm{~m}^{2} / \mathrm{g}$ ), indicating that most coke was located in the micropores. The textural properties of the pre-coked HMCM-S-CTAB and HMCM-T-CTAB samples were similar to that of pre-coked HMCM-49, implying that the supercages of all the samples were successfully blocked.

${ }^{29}$ Si MAS NMR was employed to investigate the chemical environment of the framework Si atoms in the samples before and after CTAB modification. Due to the similar chemical shifts of Si atoms on different T sites, the ${ }^{29}$ Si MAS NMR spectrum of HMCM-49 is not sharp. Fig. 2(a) shows the Gaussian fitted spectra of HMCM-49 (using the method reported in Ref. [35]). There were five resonance peaks in the range from -120 to -105 (accuracy \pm 0.2 ) for the non-equivalent framework $\mathrm{T}$ sites of the zeolite, which correspond to the $\mathrm{Si}(0 \mathrm{Al})$ units (Q4 type Si) and are the characteristic peaks for MCM-22 or MCM-49 $[36,37]$. The assignments of the resonance peaks were the same as those in Ref. $[15,16]$.

Figure 2(b) shows the ${ }^{29} \mathrm{Si}$ MAS NMR spectra of the HMCM-49, HMCM-S-CTAB and HMCM-T-CTAB samples. The distribution of $\mathrm{Si}$ atoms on different $\mathrm{T}$ sites was calculated by the peak area normalization method, and is listed in Table 2. For the HMCM-49 sample, the peak area percentage of Si atoms on the T3 site was $27.6 \%$, while after CTAB modification, it was reduced to $21.6 \%-24.5 \%$. Simultaneously, the peak area percentage of Q3 type $\mathrm{Si}$ increased from 5.1\% (HMCM-49) to 6.1\%-9.2\% (HMCM-S-CTAB or HMCM-T-CTAB). It is reasonable to assume that $\mathrm{Si}$ atoms on the T3 site were selectively extracted during CTAB modification, and that some $\mathrm{Si}$ atoms

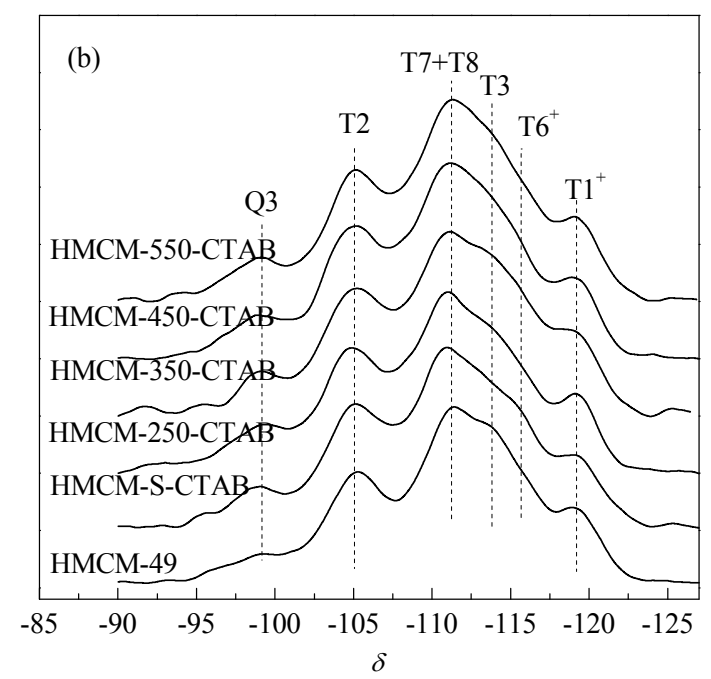

Fig. 2. ${ }^{29}$ Si MAS NMR spectra of the HMCM-49, HMCM-S-CTAB and HMCM-T-CTAB samples.

Table 2

Distribution of $\mathrm{Si}$ and $\mathrm{Al}$ in HMCM-49, HMCM-S-CTAB and HMCM-T-CTAB.

\begin{tabular}{|c|c|c|c|c|c|c|c|c|c|c|}
\hline \multirow{2}{*}{ Sample } & \multicolumn{7}{|c|}{ Distribution of Si (\%) } & \multicolumn{3}{|c|}{ Distribution of $\mathrm{Al}(\%)$} \\
\hline & $\mathrm{Q3}^{+}$ & Q3 & $\mathrm{T} 2$ & $\mathrm{~T} 7+\mathrm{T} 8$ & $\mathrm{~T} 3$ & $\mathrm{~T}^{+}$ & $\mathrm{T}^{+}+$ & T6, T7 & $\mathrm{T} 1, \mathrm{~T} 3, \mathrm{~T} 4, \mathrm{~T} 5, \mathrm{~T} 8$ & $\mathrm{~T} 2$ \\
\hline HMCM-49 & 1.0 & 5.1 & 24.7 & 24.3 & 27.6 & 8.5 & 8.8 & 47.1 & 44.6 & 8.3 \\
\hline HMCM-S-CTAB & 0.8 & 6.8 & 26.8 & 26.0 & 24.5 & 5.8 & 9.3 & 25.7 & 59.3 & 15.0 \\
\hline НМСМ-250-СТАВ & 1.6 & 9.2 & 26.1 & 25.9 & 22.5 & 6.5 & 8.2 & 27.7 & 56.9 & 15.4 \\
\hline НМСМ-350-СТАВ & 1.0 & 6.1 & 26.4 & 27.6 & 22.2 & 7.8 & 8.9 & 25.3 & 58.6 & 16.1 \\
\hline НМСМ-450-СТАВ & 0.3 & 8.5 & 24.6 & 28.5 & 22.0 & 8.1 & 8.0 & 27.6 & 57.0 & 15.4 \\
\hline НMCM-550-СТАВ & 0.5 & 7.8 & 23.8 & 29.7 & 21.6 & 8.0 & 8.6 & 26.2 & 54.3 & 19.5 \\
\hline
\end{tabular}


which were adjacent to the T3 site existed in the form of $\mathrm{Si}(\mathrm{OSi})_{3} \mathrm{OH}(\mathrm{Q} 3)$. The peak area percentage for Si atoms on the T7 and T8 sites increased from 24.3\% (HMCM-49) to 25.9\%-29.7\% (HMCM-S-CTAB or HMCM-T-CTAB), implying that some amorphous $\mathrm{Si}$ or $\mathrm{Si}$ atoms extracted from the T3 site were reinserted into the defects of the $\mathrm{T} 7$ or $\mathrm{T} 8$ sites during the process of CTAB modification.

Figure 3 shows the ${ }^{27} \mathrm{Al}$ MAS NMR spectra of HMCM-49 and the samples after CTAB modification. Two groups of peaks centered at $\delta=0$ and $\delta \approx 55$ were observed in these spectra. The first peak is related to extraframework octahedral Al species resulting from incomplete crystallization or calcination, while the latter one was assigned to 4-coordinated framework $\mathrm{Al}[35,38]$. The percent of extraframework $\mathrm{Al}$ of the samples after CTAB modification (27\%-34\%) was lower than that for HMCM-49 (40\%). In contrast, the amount of framework Al became higher. Since there was no extra Al species introduced into the solution, there were two possible reasons for this: one was the removal of amorphous $\mathrm{Al}$ from the MCM-49 zeolite and the other was the reinsertion of some extraframework $\mathrm{Al}$ atoms into the framework during the CTAB treatment. We have discussed the first possibility in the discussion of the XRD and XRF data, and we will now analyze the latter possibility.

The chemical shift of $\mathrm{Al}$ atoms on different $\mathrm{T}$ sites varies due to their different chemical environment. The peak at $\delta=55$ can be simulated with three overlapping Gaussian peaks at $\delta=49$, 55 , and $61[36,39]$. Specifically, the peak at $\delta=49$ is related to $\mathrm{Al}$ atoms on $\mathrm{T} 6$ and $\mathrm{T} 7$ sites, the peak at $\delta=55$ is assigned to $\mathrm{Al}$ atoms on $\mathrm{T} 1, \mathrm{~T} 3, \mathrm{~T} 4, \mathrm{~T} 5$, and $\mathrm{T} 8$ sites, and the peak at $\delta=61$ is attributed to $\mathrm{Al}$ atoms on the $\mathrm{T} 2$ site $[36,39]$. The proportions of the different peaks were also calculated by the area normalization method. The results are listed in Table 2. For all the CTAB modified samples, the peak area percentage for framework $\mathrm{Al}$ atoms on the T1, T3, T4, T5, and T8 sites were $54.3 \%-59.3 \%$, while that of HMCM-49 was only $44.6 \%$. Simultaneously, the peak area percentage for $\mathrm{Al}$ atoms on the $\mathrm{T} 2$ site increased from $8.3 \%$ (HMCM-49) to $15.0 \%-19.5 \%$

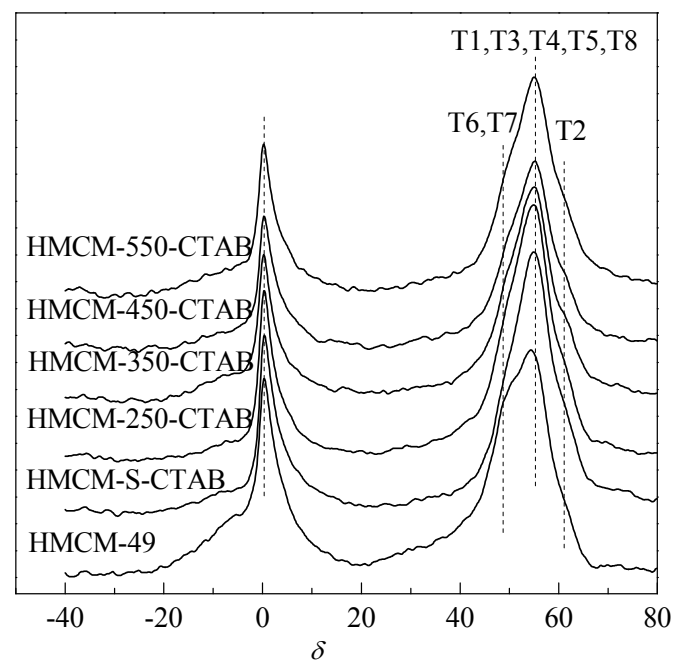

Fig. 3. ${ }^{27} \mathrm{Al}$ MAS NMR spectra of the HMCM-49, HMCM-S-CTAB and HMCM- T-CTAB samples.
(HMCM-S-CTAB or HMCM-T-CTAB). Obviously, the change of the peak area percentage for $\mathrm{Al}$ atoms on the different $\mathrm{T}$ sites support the explanation that some extraframework $\mathrm{Al}$ atoms were reinserted into the framework during the CTAB treatment. Combining the ${ }^{29} \mathrm{Si}$ MAS NMR and ${ }^{27} \mathrm{Al}$ MAS NMR results, it can be deduced that extraframework $\mathrm{Al}$ atoms were inserted into the framework of the zeolite by selectively substituting Si atoms on the T3 site and by directly filling in the defects on the T2 or T3 sites. Although we cannot be sure about what happened between CTAB and the $\mathrm{Si}$ or $\mathrm{Al}$ atoms in the MCM-49 zeolite, we were certain that something else happened in addition to the removal of amorphous particles. Guo's group [40] have studied the TPAOH modification of nanocrystalline ZSM-5 zeolite, and suggested that the modification led to desilication, dealumination, and secondary crystallization of the zeolite, resulting in the migration of non-framework $\mathrm{Si}$ and non-framework Al to the zeolite surface.

From Ref. [15], we know that the MCM-49S and CT materials contained HMI in different pore systems. If it is assumed that the HMI-containing region is inert to CTAB modification (extension of the assumption from Ref. [41]), then we can deduce that for the HMCM-250-CTAB sample, the Si extraction or $\mathrm{Al}$ reinsertion mainly occurred on the surface pockets, and for the HMCM-350-CTAB sample, the CTAB modification occurred not only on the surface pockets but also in the supercages, while for HMCM-450-CTAB and HMCM-550-CTAB, almost all the pore systems were accessible to CTAB. However, for the HMCM-S-CTAB sample, though nominally there were no HMI-free regions, part of the HMI on the surface pockets would be eluted during the CTAB treatment, i.e., the Si extraction or $\mathrm{Al}$ reinsertion mainly occurred on the surface pockets of the HMCM-S-CTAB sample. Furthermore, considering the amount of HMI-free regions (HMCM-S-CTAB $\approx$ HMCM-250-CTAB < HMCM-350-CTAB < HMCM-450-CTAB $\approx$ HMCM-550-CTAB), the ratio of available $\mathrm{CTAB}$ to the volume of "attackable" zeolite [41] showed an inverse sequence as follows: HMCM-S-CTAB $\approx$ HMCM-250-CTAB > HMCM-350-CTAB > HMCM-450-CTAB $\approx$ HMCM-550-CTAB. The degree of CTAB modification seemed related to the amount of HMI-free regions accessible to CTAB and the available concentration of CTAB.

The above results suggested that during the CTAB treatment process, there existed the cleaning off of amorphous $\mathrm{Al}$ and extraframework $\mathrm{Al}$ atoms were inserted into the framework of the zeolite, although there was no obvious trend among the HMCM-49, HMCM-S-CTAB and HMCM-T-CTAB samples. The reason may be that the two processes existed in competition when the CTAB modified the MCM-49S and CT samples with different HMI contents. The mechanism is not yet clear.

\subsubsection{Effect of CTAB modification on the zeolite acidity}

The acidity of HMCM-49 and the samples modified by CTAB were measured by $\mathrm{NH}_{3}$-TPD. The results are presented in Fig. 4. The concentration of the acid sites was determined by the amount of desorbed $\mathrm{NH}_{3}$, while the $\mathrm{NH}_{3}$ desorption peak temperature was related to the strength of the acid sites [42]. The $\mathrm{NH}_{3}$-TPD profiles were fitted with three Gaussian peaks, and the acid concentrations of the different samples were calculat- 


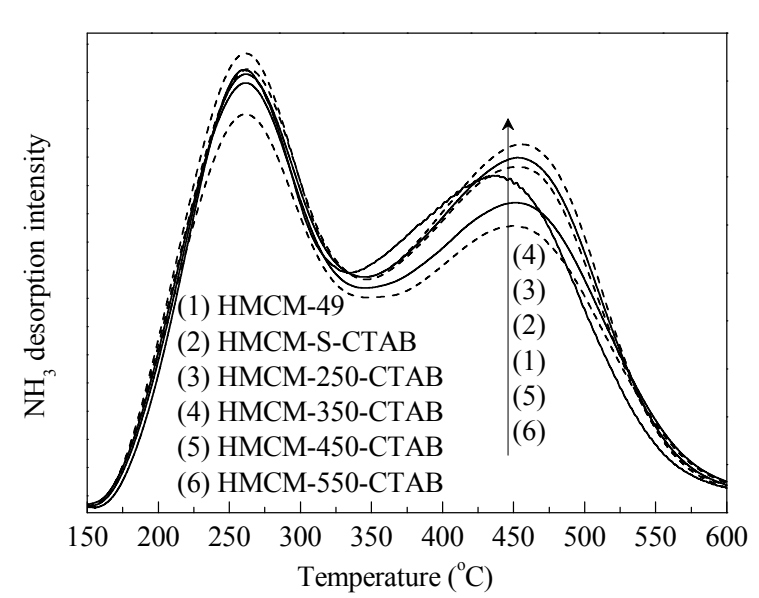

Fig. 4. $\mathrm{NH}_{3}-\mathrm{TPD}$ profiles of the HMCM-49, HMCM-S-CTAB and HMCM-T-CTAB samples.

ed and listed in Table 3. The desorption peaks of HMCM-49 centered at 253,338 and $443{ }^{\circ} \mathrm{C}$, were due to the weak, medium and strong acid sites, respectively. For the HMCM-S-CTAB, HMCM-250-CTAB and HMCM-350-CTAB samples, the total acid concentrations showed a slight increase compared with that of HMCM-49 (0.87 mmol/g). For the HMCM-450-CTAB and HMCM-550-CTAB samples, the total acid concentrations decreased gradually and were less than that of HMCM-49. The HMCM-350-CTAB sample has the highest total acid concentration $(0.96 \mathrm{mmol} / \mathrm{g})$.

The acidity of the samples was further characterized by Py-IR. The Py-IR spectra are presented in Fig. 5. The band at $1454 \mathrm{~cm}^{-1}$ was attributed to adsorbed pyridine bonded to Lewis acid sites, while the absorption band at $1545 \mathrm{~cm}^{-1}$ was assigned to pyridine interacting with Brönsted acid sites, and the band at $1490 \mathrm{~cm}^{-1}$ was due to pyridine interacting with both Brönsted acid sites and Lewis acid sites [43]. The band areas for the Brönsted acid sites for the samples after CTAB modification were larger than that of HMCM-49, while the band areas for the Lewis acid sites were smaller. With the increase of HMI-free regions, the band areas corresponding to the Brönsted acid sites increased first, and then decreased, which was similar to the trend of the total acid concentration determined by $\mathrm{NH}_{3}$-TPD.

To calculate the acid concentration, 1.67 and $2.22 \mathrm{~cm} / \mu \mathrm{mol}$ were taken as the integrated molar extinction coefficient of the Brönsted and Lewis acid sites, respectively, as suggested in Ref. [44]. The calculated concentration of Brönsted and Lewis acid sites are listed in Table 3. The Brönsted acid concentrations of

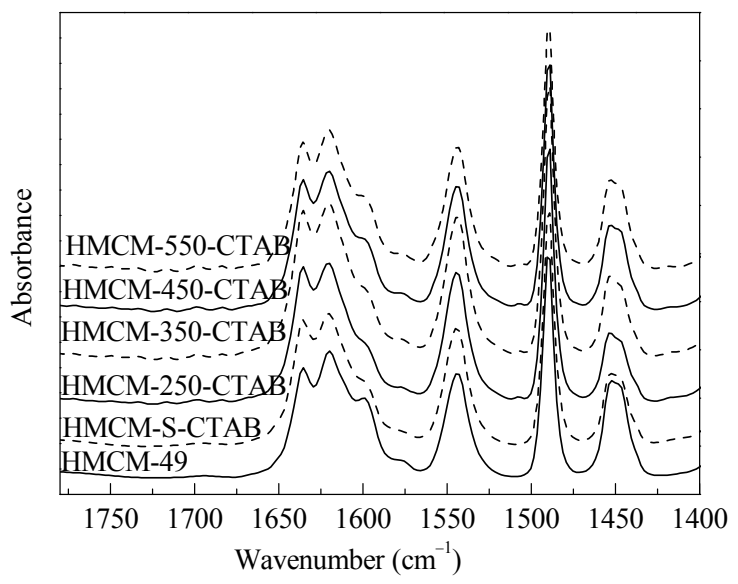

Fig. 5. Py-IR spectra of HMCM-49, HMCM-S-CTAB and HMCM-T-CTAB samples.

all the samples after CTAB treatment were higher than that of HMCM-49, while the Lewis acid concentrations of the formers were lower than that of the latter. Both the Brönsted acid concentration and concentration ratio of Brönsted to Lewis acid sites $(\mathrm{B} / \mathrm{L})$ increased first, and then decreased with the decrease of HMI content before the CTAB modification, and reached the highest values $(0.40 \mathrm{mmol} / \mathrm{g}$ and 2.5$)$ for the HMCM-350-CTAB sample.

The DRIFTS spectra of the HMCM-49, HMCM-S-CTAB and HMCM-T-CTAB samples are given in Fig. 6. It was obvious that the intensity of the band at $3620 \mathrm{~cm}^{-1}$, associated with bridging $\mathrm{OH}$ groups [26,45-47], increased markedly after the CTAB modification. Specifically, with the decrease of HMI retained in the sample, the intensity of the band at $3620 \mathrm{~cm}^{-1}$ increased first, and then decreased. The HMCM-350-CTAB sample showed the highest intensity for this band. This reflected the trend of Brönsted acid concentration [26,46], which was in accordance with the Py-IR results. The band at $3747 \mathrm{~cm}^{-1}$, assigned to surface silanol groups [26,45-47], was of almost the same intensity for all the samples. The intensity of the band at $3665 \mathrm{~cm}^{-1}$, attributed to $\mathrm{Al}-\mathrm{OH}$ groups where $\mathrm{Al}$ is connected with the zeolite framework by one or two chemical bonds $[26,45]$, decreased slightly after the CTAB modification, indicating the decrease of extraframework $\mathrm{Al}$ species, which was in line with the ${ }^{27} \mathrm{Al}$ MAS NMR result.

In the previous section, we deduced that the extraframework $\mathrm{Al}$ atoms insert into the framework by selectively substituting Si atoms on the T3 site or directly filling in the defects on the $\mathrm{T} 2$ or $\mathrm{T} 3$ sites during the CTAB modification. This was fur-

Table 3

Acid site distribution of the HMCM-49, HMCM-S-CTAB and HMCM-T-CTAB samples.

\begin{tabular}{|c|c|c|c|c|c|c|c|}
\hline Sample & $\begin{array}{l}\text { Weak acid } \\
(\mathrm{mmol} / \mathrm{g})\end{array}$ & $\begin{array}{l}\text { Medium acid } \\
(\mathrm{mmol} / \mathrm{g})\end{array}$ & $\begin{array}{c}\text { Strong acid } \\
(\mathrm{mmol} / \mathrm{g})\end{array}$ & $\begin{array}{c}\text { Total } \\
(\mathrm{mmol} / \mathrm{g}) \\
\end{array}$ & $\begin{array}{c}\text { Brönsted acid } \\
(\mathrm{mmol} / \mathrm{g})\end{array}$ & $\begin{array}{l}\text { Lewis acid } \\
(\mathrm{mmol} / \mathrm{g})\end{array}$ & $\begin{array}{l}\mathrm{B} / \mathrm{L} \\
\text { ratio } \\
\end{array}$ \\
\hline HMCM-49 & $0.34(253)^{a}$ & $0.14(338)$ & $0.39(443)$ & 0.87 & 0.30 & 0.21 & 1.4 \\
\hline HMCM-S-CTAB & $0.41(259)$ & $0.15(363)$ & $0.37(457)$ & 0.93 & 0.35 & 0.16 & 2.2 \\
\hline НМСМ-250-СТАВ & 0.39 (259) & $0.15(361)$ & $0.38(458)$ & 0.92 & 0.38 & 0.16 & 2.4 \\
\hline НMCM-350-СТАВ & $0.40(259)$ & $0.16(361)$ & $0.40(458)$ & 0.96 & 0.40 & 0.16 & 2.5 \\
\hline НМСМ-450-СТАВ & $0.38(259)$ & $0.14(361)$ & $0.34(458)$ & 0.86 & 0.36 & 0.19 & 1.9 \\
\hline НМСМ-550-СТАВ & $0.36(259)$ & $0.14(359)$ & $0.32(458)$ & 0.82 & 0.34 & 0.19 & 1.8 \\
\hline
\end{tabular}

a Data in parentheses were the peak temperatures $\left({ }^{\circ} \mathrm{C}\right)$ in the $\mathrm{NH}_{3}$-TPD profiles. 


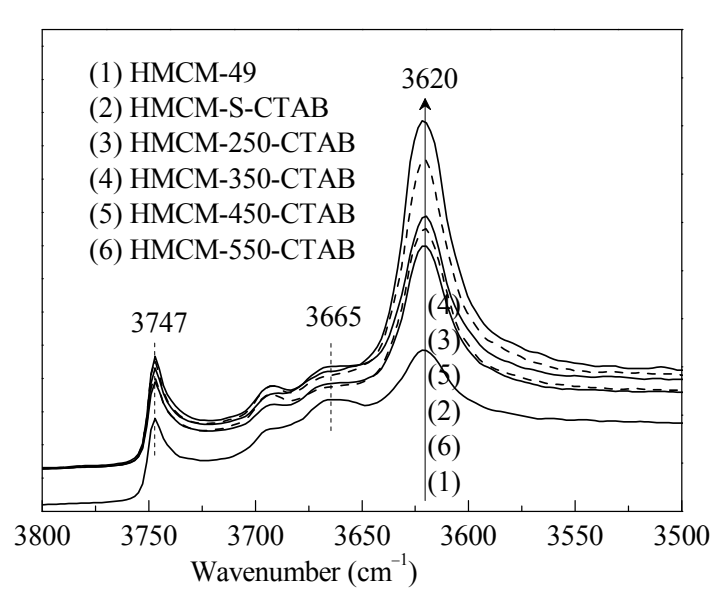

Fig. 6. DRIFTS spectra of HMCM-49, HMCM-S-CTAB and HMCM-T-CTAB samples.

ther supported by the Py-IR and DRIFTS results, which showed the increase of Brönsted acid sites and the decrease of Lewis acid sites. In addition, the acidity of the samples was also related to the cleaning off of amorphous particles during the CTAB treatment process. These two factors resulted into the change of Brönsted acid concentration for the HMCM-49, HMCM-S-CTAB and HMCM-T-CTAB samples shown in Table 3, although we could not estimate the proportion of the separate contribution from these two factors. The HMCM-250-CTAB and HMCM-350-CTAB samples had higher concentrations of Brönsted acid than the other samples, implying that there were more extra-framework $\mathrm{Al}$ species inserted into the framework or cleaned off from the crystals for these two samples.

\subsection{Effect of CTAB modification on catalytic property}

\subsubsection{Acylation performance of HMCM-49 and samples modified by CTAB}

The acylation of AN with AA was used as the probe reaction to investigate the catalytic performance of the HMCM-49, HMCM-S-CTAB and HMCM-T-CTAB samples. The AA conversions versus time on stream (TOS) over the different samples are shown in Fig. 7. When HMCM-49 was used as catalyst, the initial conversion of AA (at TOS of $2 \mathrm{~h}$ ) was $51.4 \%$, and the detected products were acetic acid (AC) and methoxyacetophenone (MAP), with the selectively of $52.7 \%$ and $47.3 \%$, respectively. Most of the MAP was in the para form (the selectivity to $p$-MAP > 98\%), which was consistent with the results reported in Ref. [48] After $9 \mathrm{~h}$ of TOS, the AA conversion decreased to $28.9 \%$, while the selectivity to $p$-MAP showed almost no change.

Compared with HMCM-49, the AA initial conversion for the samples after CTAB modification increased obviously, and the selectivity to the products showed almost no change. In particular, for the HMCM-S-CTAB catalyst, the AA initial conversion was $73.7 \%$, which decreased to $53.8 \%$ after reaction for $9 \mathrm{~h}$, showing a similar decline (19.9\%) with that of HMCM-49 $(22.5 \%)$. For the other catalysts, with the decrease of HMI content before the CTAB modification, the AA initial conversions

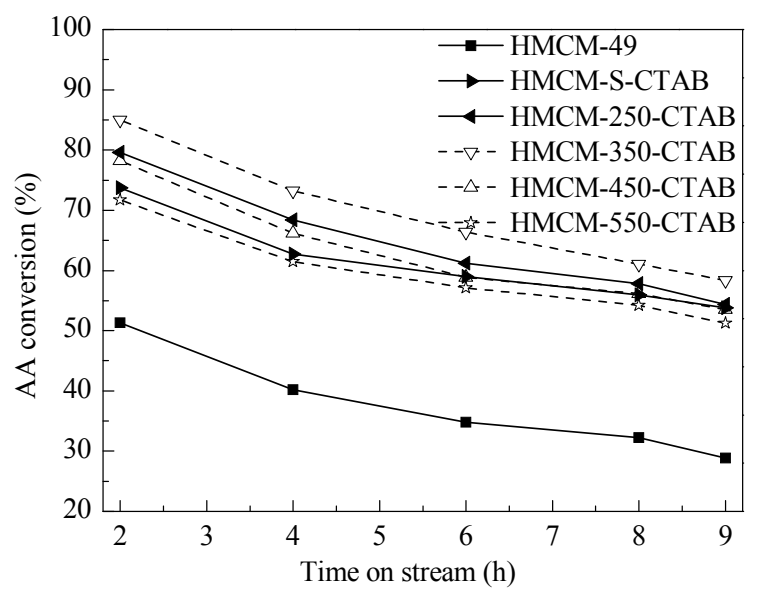

Fig. 7. Catalytic performance of the HMCM-49, HMCM-S-CTAB and HMCM-T-CTAB samples for the acylation of anisole with acetic anhydride. Reaction conditions: $1.0 \mathrm{MPa}, 110{ }^{\circ} \mathrm{C}$, WHSV $(\mathrm{AN}+\mathrm{AA})=$ $10.2 \mathrm{~h}^{-1}, n(\mathrm{AN}) / n(\mathrm{AA})=5$.

increased first, and then decreased. Simultaneously, the decline of AA conversion for the series of catalysts modified with CTAB was comparable with that for HMCM-49. For the HMCM-350-CTAB catalyst, the AA initial conversion increased to the highest value of $85.0 \%$, about $34 \%$ higher than that of HMCM-49. On the other hand, the AA initial conversion on the HMCM-550-CTAB catalyst decreased to $71.8 \%$. In conclusion, the CTAB treatment obviously increased the initial conversion of AA, but had no effect on product selectivity.

\subsubsection{Relation between acylation catalytic performance and acidity}

The main factors influencing the catalytic behavior of AN acylation with AA on zeolite catalysts are the acidity and textural properties [1]. Since the textural properties of the samples after CTAB modification were quite similar to that of HMCM-49, the difference in their catalytic performance can be attributed to the variation of acidity. The AA initial conversion and Brönsted acid concentrations of HMCM-49, HMCM-S-CTAB and HMCM-T-CTAB samples are shown in Fig. 8. It is obvious that the AA initial conversion was positively correlated with the Brönsted acid concentration since both increased first and then decreased with the decrease of HMI content before the CTAB modification. This result is consistent with our previous work [48], in which it was shown that strong Brönsted acid sites were involved in the acylation of AN with AA when Beta zeolite was used as catalyst.

\subsubsection{Effect of CTAB modification on the catalytic perfor- mance of the different pore systems}

In order to further confirm the nature of acid sites interacting with $\mathrm{CTAB}$, we investigated the catalytic performances of different pore systems over the tested zeolite catalysts for the acylation of AN with AA (according to the method of Xu's group [26]). The relation between AA conversions in the different pore systems with TOS for the different samples is shown in Fig. 9. The catalytic role of the different pore systems was esti- 


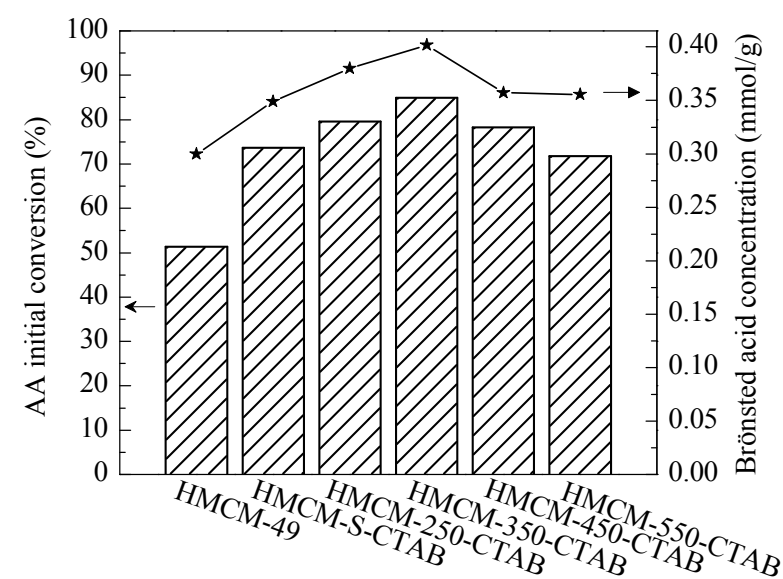

Fig. 8. Correlation of Brönsted acid concentration with AA initial conversion on the HMCM-49, HMCM-S-CTAB and HMCM-T-CTAB samples. Reaction conditions: $1.0 \mathrm{MPa}, 110{ }^{\circ} \mathrm{C}, \mathrm{WHSV}(\mathrm{AN}+\mathrm{AA})=10.2$ $\mathrm{h}^{-1}, n(\mathrm{AN}) / n(\mathrm{AA})=5$, time on stream $=2 \mathrm{~h}$.

mated based on the following postulates. Taking HMCM-49 as an example, we suppose that when HMCM-49 and HMCM-49-xy were used as the catalyst, the difference between their AA conversions can be attributed to the contribution of supercages. When HMCM-49-xy and HMCM-49-xy-DMQ were used as the catalyst, the difference between their AA conversions can be assigned to the contribution of surface pockets.

When HMCM-49 was used to catalyze the acylation reaction, the AA initial conversion in the surface pockets was $38.5 \%$, corresponding to $75 \%$ of the activity (51.4\%), while the AA initial conversion in the supercages was only $10.3 \%$, corresponding to $20 \%$ of the activity. The AA initial conversion in the sinusoidal channels was only $2.6 \%$, and can be ignored in the following discussion. It was obvious that for the HMCM-49 sample, the surface pockets were the main contributors to the activity for the acylation of AN with AA. This was consistent with the result reported by Guidotti et al. [6]. They concluded that the acylation was mainly carried out on the accessible acid sites which were located on the external hemicages of the MWW zeolite, but they did not quantify the catalytic performance of the three pore systems. With the progress of reaction, both the activity of the surface pockets and supercages decreased gradually. When the reaction time on stream was $9 \mathrm{~h}$, the AA conversion on the surface pockets decreased to $21.2 \%$, while that in the supercages decreased to $6.0 \%$.

When HMCM-S-CTAB was used as catalyst, the AA conversion on its surface pockets was $58.9 \%$ at the initial reaction stage, which was $20.4 \%$ higher than that of HMCM-49 (38.5\%), and this decreased to $41.4 \%$ at the reaction time of $9 \mathrm{~h}$. It is interesting to notice that this decline percentage of AA conversion in the surface pockets $(17.5 \%)$ was comparable with that of HMCM-49 (17.3\%). The AA conversion in the supercages at a TOS of $2 \mathrm{~h}$ was $11.0 \%$, which was similar to that of HMCM-49 (10.3\%), and there was nearly no change to the TOS of $9 \mathrm{~h}$. The result clearly indicated that the CTAB modification used in this work mainly happened on the surface pockets of the zeolite, which is in good agreement with our discussion above.

For the HMCM-350-CTAB catalyst, the AA initial conversion in the surface pockets and its decline were similar to that of HMCM-S-CTAB. The AA initial conversion in the supercages was $20.3 \%$, nearly twice as high as that of HMCM-S-CTAB (11.0\%), and it decreased to $11.6 \%$ at the TOS of $9 \mathrm{~h}$. This indicated that for the HMCM-350-CTAB catalyst, deactivation happened both in the supercages and in the surface pockets. Compared to the corresponding data of the HMCM-S-CTAB catalyst, we can say that the CTAB modification of the C350 sample oc-
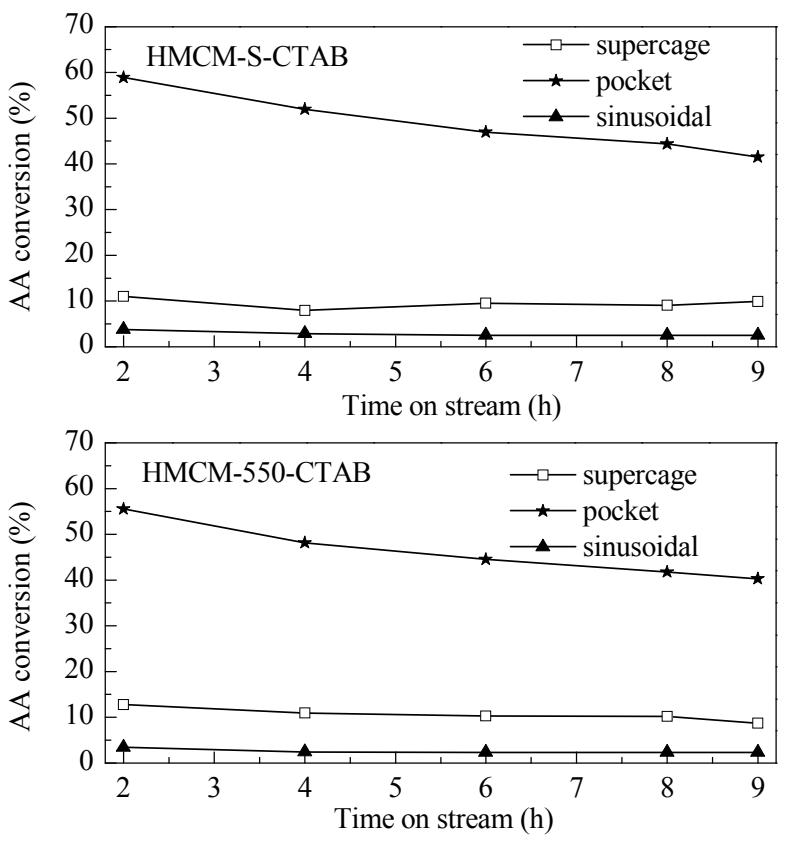

Fig. 9. AA conversion versus time on stream for the different pore systems of the HMCM-49, HMCM-S-CTAB, HMCM-350-CTAB and HMCM-550-CTAB samples. Reaction conditions: $1.0 \mathrm{MPa}, 110^{\circ} \mathrm{C}, \mathrm{WHSV}(\mathrm{AN}+\mathrm{AA})=10.2 \mathrm{~h}^{-1}, n(\mathrm{AN}) / n(\mathrm{AA})=5$. 
curred not only in the surface pockets, but also in the supercages, which was also in accordance with our above discussion.

When the HMCM-550-CTAB catalyst was used, the AA initial conversion on the surface pockets was $55.6 \%$, which was $17.1 \%$ higher than that of HMCM-49 (38.5\%). The AA initial conversion on the supercages was $12.7 \%$, a little higher than that of HMCM-49 (10.3\%), indicating that the CTAB modification of this sample occurred on both the surface pockets and the supercages. Because the acylation of AN with AA is nearly forbidden in the sinusoidal channels of MCM-49 zeolite, there was no way to see if the CTAB modification occurred in the sinusoidal channels. However, the increases of AA initial conversion in the surface pockets and supercages of HMCM-550-CTAB were both lower than that of HMCM-350-CTAB, implying that the degree of CTAB modification was closely related to the available concentration of $\mathrm{CTAB}$ in the process (HMCM-350-CTAB > HMCM-550-CTAB), as discussed above.

In conclusion, compared with the HMCM-49 catalyst, the increase of initial activity on HMCM-S-CTAB was attributed to the increase in activity on the surface pockets, while for HMCM-350-CTAB and HMCM-550-CTAB, it was related to the increase of activity in both surface pockets and supercages. This further confirmed that CTAB interacted with different sites for different samples, which is in accordance with characterization results. However, it is worth noting that we do not know if CTAB modification can occur in the sinusoidal channels of HMCM-550-CTAB.

\section{Conclusions}

The partially de-templated MCM- 49 zeolite contained residual HMI in different pore systems. CTAB treatment cleaned off some amorphous particles from the zeolite and attacked HMI-free regions whereby extraframework Al species selectively substituted $\mathrm{Si}$ atoms on the T3 site and directly filled in the defects on T2 or T3 sites. The Brönsted acid concentration of the samples after CTAB modification was all higher than the HMCM-49 sample. Samples modified with CTAB used to catalyze the acylation of AN with AA had catalytic activity that displayed a positive correlation with the Brönsted acid concentration. The acylation of AN with AA was mainly carried out on the acid sites located on the surface pockets of the MCM-49 zeolite, and not as much on the acid sites located in the supercages.

\section{References}

[1] Zhao D S, Wang J L, Zhang J. Catal Lett, 2008, 126: 188

[2] Wine G, Pham-Huu C, Ledoux M J. Catal Commun, 2006, 7: 768

[3] Bai G Y, Dou H Y, Qiu M D, He F, Fan X X, Ma Z. Res Chem Intermediat, 2010, 36: 483

[4] Bejblova M, Prochazkova D, Cejka J. ChemSusChem, 2009, 2: 486

[5] Serrano D P, Garcia R A, Vicente G, Linares M, Prochazkova D, Cejka J. J Catal, 2011, 279: 366

[6] Guidotti M, Coustard J M, Magnoux P, Guisnet M. Pure Appl Chem, 2007, 79: 1833

[7] Bai G Y, Dou H Y, Qiu M D, Fan X X, He F, Niu L B, Ma Z. Catal Lett, 2010, 138: 187

[8] Sartori G, Maggi R. Chem Rev, 2006, 106: 1077

[9] Yoo W C, Zhang X Y, Tsapatsis M, Stein A. Microporous Mesoporous Mater, 2012, 149: 147

[10] Verboekend D, Pérez-Ramírez J. Catal Sci Technol, 2011, 1: 879

[11] Ivanova I I, Kasyanov I A, Maerle A A, Zaikovskii V I. Microporous Mesoporous Mater, 2014, 189: 163

[12] Ivanova I I, Knyazeva E E. Chem Soc Rev, 2013, 42: 3671

[13] Schmidt F, Lohe M R, Büchner B, Giordanino F, Bonino F, Kaskel S. Microporous Mesoporous Mater, 2013, 165: 148

[14] Ordomsky V V, Ivanova I I, Knyazeva E E, Yuschenko V V,

\section{Graphical Abstract}

Chin. J. Catal., 2015, 36: 1766-1776 doi: 10.1016/S1872-2067(15)60887-7

\section{CTAB modification of MCM-49 zeolite containing HMI and its acylation of anisole}

Huijuan Wei, Sujuan Xie, Kefeng Liu, Wenjie Xin, Xiujie Li, Shanhe Liu, Shunming Gu, Shenglin Liu, Longya Xu* Dalian Institute of Chemical Physics, Chinese Academy of Sciences; University of Chinese Academy of Sciences; Petrochemical Research Institute of PetroChina Company Limited; Anhui Costar Biochemical Co. Ltd.
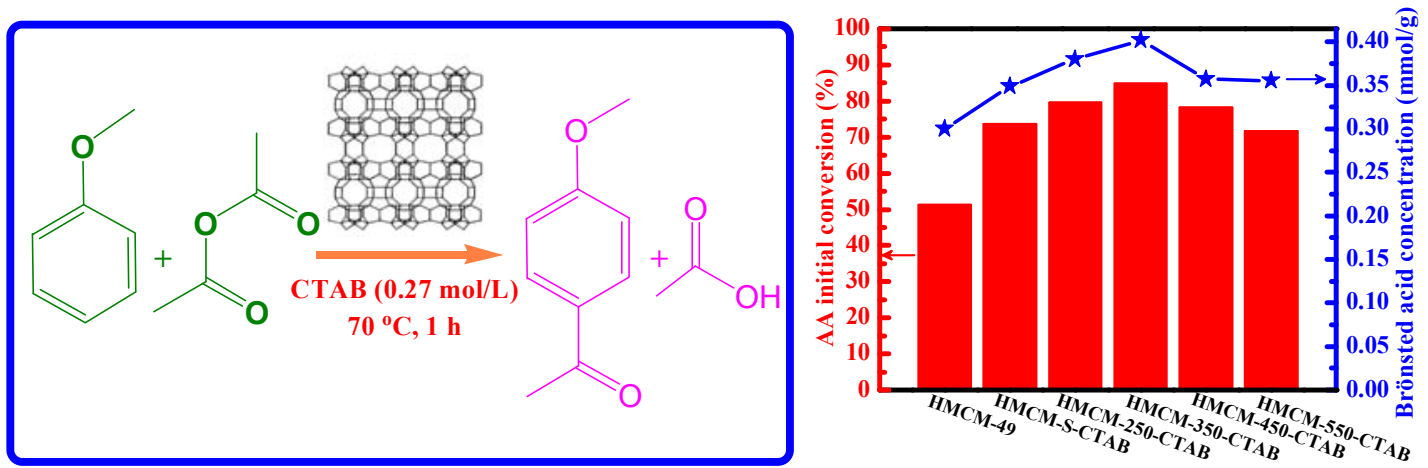

Acetic anhydride conversion over HMCM-49 after CTAB modification displayed a positive correlation with the Brönsted acid concentration, which was higher after CTAB modification than on the original HMCM-49. 
Zaikovskii V I. J Catal, 2012, 295: 207

[15] Wei H J, Xie S J, Gao N N, Liu K F, Liu X H, Xin W J, Li X J, Liu S L, Xu L Y. Appl Catal A, 2015, 495: 152

[16] Liu K F, Xie S J, Wei H J, Li X J, Liu S L, Xu L Y. Appl Catal A, 2013, 468: 288

[17] Liu K F, Xie S J, Xu G L, Li Y N, Liu S L, Xu L Y. Appl Catal A, 2010, 383: 102

[18] Gao N N, Xie S J, Liu S L, An J, Zhu X X, Hu L Y, Wei H J, Li X J, Xu L Y. Catal Lett, 2014, 144: 1296

[19] Corma A, Fornes V, Martinez-Triguero J, Pergher S B. J Catal, 1999, 186: 57

[20] Corma A, Fornes V, Pergher S B, Maesen T L M, Buglass J G. Nature, 1998, 396: 353

[21] Maheshwari S, Martinez C, Portilla M T, Llopis F J, Corma A, Tsapatsis M. J Catal, 2010, 272: 298

[22] Chlubna P, Roth W J, Zukal A, Kubu M, Pavlatova J. Catal Today, 2012, 179: 35

[23] Maheshwari S, Jordan E, Kumar S, Bates F S, Penn R L, Shantz D F, Tsapatsis M. J Am Chem Soc, 2008, 130: 1507

[24] Roth W J, Cejka J. Catal Sci Technol, 2011, 1: 43

[25] Liu K F, Liu S L, Xie S J, Wei H J, Song C, Li X J, Xu L Y. Catal Lett, 2014, 144: 1223

[26] Liu K F, Xie S J, Liu S L, Xu G L, Gao N N, Xu L Y. J Catal, 2011, 283: 68

[27] Laforge S, Martin D, Guisnet M. Microporous Mesoporous Mater, 2004, 67: 235

[28] Matias P, Lopes J M, Laforge S, Magnoux P, Guisnet M, Ramôa Ribeiro F. Appl Catal A, 2008, 351: 174

[29] Bennett J M, Chang C D, Lawton S L, Leonowicz M E, Lissy D N, Rubin M K. US Patent 5 236 575. 1993

[30] van Miltenburg A, Pawlesa J, Bouzga A M, Zilkova N, Cejka J, Stöcker M. Top Catal, 2009, 52: 1190

[31] Garcia-Martinez J, Johnson M, Valla J, Li K H, Ying J Y. Catal Sci Technol, 2012, 2: 987

[32] Khitev Y P, Kolyagin Y G, Ivanova I I, Ponomareva O A,
Thibault-Starzyk F, Gilson J P, Fernandez C, Fajula F. Microporous Mesoporous Mater, 2011, 146: 201

[33] Inagaki S, Ogura M, Inami T, Sasaki Y, Kikuchi E, Matsukata M. Microporous Mesoporous Mater, 2004, 74: 163

[34] Chal R, Cacciaguerra T, van Donk S, Gerardin C. Chem Commun, 2010, 46: 7840

[35] Delitala C, Alba M D, Becerro A I, Delpiano D, Meloni D, Musu E, Ferino I. Microporous Mesoporous Mater, 2009, 118: 1

[36] Kennedy G J, Lawton S L, Fung A S, Rubin M K, Steuernagel S. Catal Today, 1999, 49: 385

[37] Ma D, Deng F, Fu R Q, Han X W, Bao X H.J Phys Chem B, 2001, 105: 1770

[38] Fyfe C A, Feng Y, Grondey H, Kokotailo G T, Gies H. Chem Rev, 1991, 91: 1525

[39] Lawton S L, Fung A S, Kennedy G J, Alemany L B, Chang C D, Hatzikos G H, Lissy D N, Rubin M K, Timken H K C, Steuernagel S, Woessner D E. J Phys Chem, 1996, 100: 3788

[40] He Y P, Liu M, Dai C Y, Xu S T, Wei Y X, Liu Z M, Guo X W. Chin J Catal (何英萍, 刘民,代成义, 徐舒涛, 魏迎旭, 刘中民, 郭新闻. 催化 学报), 2013, 34: 1148

[41] Pérez-Ramírez J, Abelló S, Bonilla A, Groen J C. Adv Funct Mater, 2009, 19: 164

[42] Lenarda M, Da Ros M, Casagrande M, Storaro L, Ganzerla R. Inorg Chim Acta, 2003, 349: 195

[43] Nur H, Ramli Z, Efendi J, Rahman A N A, Chandren S, Yuan L S. Catal Commun, 2011, 12: 822

[44] Emeis C A. J Catal, 1993, 141: 347

[45] Awayssa O, Al-Yassir N, Aitani A, Al-Khattaf S. Appl Catal A, 2014, 477: 172

[46] Gora-Marek K, Derewinski M, Sarv P, Datka J. Catal Today, 2005, 101: 131

[47] Gora-Marek K, Tarach K, Tekla J, Olejniczak Z, Kustrowski P, Liu L C, Martinez-Triguero J, Rey F. J Phys Chem C, 2014, 118: 28043

[48] Wei H J, Liu K F, Xie S J, Xin W J, Li X J, Liu S L, Xu L Y.J Catal, 2013, 307: 103

\title{
不同模板剂含量MCM-49分子耖的CTAB修饰及在苯甲醚酰基化反应中的应用
}

\author{
魏会娟 ${ }^{\mathrm{a}, \mathrm{b}}$, 谢素娟 ${ }^{\mathrm{a}}$, 刘克峰 ${ }^{\mathrm{a}, \mathrm{c}}$, 辛文杰 ${ }^{\mathrm{a}}$, 李秀杰 ${ }^{\mathrm{a}}$, 刘善和 ${ }^{\mathrm{d}}$, 谷顺明 ${ }^{\mathrm{d}}$, 刘盛林 ${ }^{\mathrm{a}}$, 徐龙伢 ${ }^{\mathrm{a}}{ }^{*}$ \\ a中国科学院大连化学物理研究所, 辽宁大连 116023 \\ b 中国科学院大学, 北京 100049 \\ ${ }^{\mathrm{c}}$ 中国石油天然气股份有限公司石油化工研究院, 北京 100029 \\ d安徽国星生物化学有限公司, 安徽当涂243100
}

摘要: 芳香族化合物的Friedel-Crafts酰基化反应是制备芳香酮的一类重要反应, 传统的Lewis酸(如 $\mathrm{AlCl}_{3}$ )和质子酸(如 $\mathrm{H}_{2} \mathrm{SO}_{4}$ )催化 剂易制备, 价格便宜, 但存在对环境污染严重、与产物难分离等问题. 因此, 近年来研究者一直致力于环境友好催化剂的研发, 其 中分子篮因选择性好、与产物易分离、可再生和无污染等优点而日益受到人们的重视, 尤其是MWW分子篮, 由于具有较多的外 表面酸性位, 而在酰基化反应中表现出良好的抗积碳性能. 本课题组曾讨论了对一系列不同模板剂(六亚甲基亚胺, HMI)含量的 MCM-49分子笛进行 $\mathrm{NaOH}$ 与十六烷基三甲基溴化铵(CTAB)共处理的情况, 而本文重点考察的是只用 CTAB处理不同HMI含量的 MCM-49分子篎时, 其结构与酸性会如何变化, 改性前后样品的结构与酸性借助XRD, $\mathrm{N}_{2}$ 吸脱附等温线测试, ${ }^{29} \mathrm{Si}$ 与 ${ }^{27} \mathrm{Al} \mathrm{MAS}$ NMR, $\mathrm{NH}_{3}$-TPD, Py-IR与漫反射傅里叶变换红外光谱(DRIFTS)等技术进行表征. 另外, 将一系列样品用于催化苯甲醚(AN)与乙 酸䣶(AA)的酰基化反应, 考察CTAB处理对MCM-49分子笁催化性能的影响.

将含模板剂HMI的MCM-49分子篮原粉在不同温度 $\left(250,350,450\right.$ 或 $\left.550{ }^{\circ} \mathrm{C}\right)$ 下焙烧, 得到一系列不同孔道系统内保留HMI的样 品, 随后采用 $\mathrm{CTAB}$ 溶液 $(0.27 \mathrm{~mol} / \mathrm{L})$ 对其在 $70^{\circ} \mathrm{C}$ 下进行后处理 $1 \mathrm{~h}$. 结构表征的结果表明, 在脱除模板剂 $\mathrm{HMI}$ 及 $\mathrm{CTAB}$ 处理的过程 中, 分子篮骨架结构基本未被破坏, 同时, CTAB处理不能向分子篮中引入任何形式的介孔, 无论是晶内介孔还是晶间介孔. 在 $\mathrm{CTAB}$ 处理时, 可以清除分子篮中部分无定形物种, 尤其是无定形A 1 物种, 同时也可能发生部分非骨架 $\mathrm{Al}$ 原子重新进入分子篮骨 架的情况, 造成骨架铝的比例相对提高. 根据 ${ }^{29} \mathrm{Si}$ 与 $^{27} \mathrm{Al}$ MAS NMR结果可以推断, 进入分子篮骨架的Al原子可能会取代T3位置上 
的 $\mathrm{Si}$ 原子, 亦或直接进入 $\mathrm{T} 2$ 或T3位置缺陷位. 酸性表征的结果表明, CTAB修饰后样品Brönsted酸量比HMCM-49明显提高, 并随 HMI含量的逐渐降低呈现先增加后降低的趋势, 而Lewis酸量则相对于HMCM-49有所降低.

将一系列CTAB修饰前后的MCM-49样品用于催化AN与AA的酰基化反应, 反应条件为: 压力 $1.0 \mathrm{MPa}$ 、温度 $110^{\circ} \mathrm{C}$ 、总质量 空速WHSV (AN+AA)为 $10.2 \mathrm{~h}^{-1}$ 及原料中 AN与 $\mathrm{AA}$ 的摩尔比为 $5: 1$. 反应数据表明, 相对于HMCM-49样品, CTAB修饰后样品对应 的AA转化率显著提高(初始转化率由 $51.4 \%$ 最高增加至 $85.0 \%$ ), 并随CTAB处理过程中HMI含量的逐渐降低呈现先增加后降低的 趋势, 而产物选择性则基本没有变化. 各样品的 $\mathrm{AA}$ 初始转化率与其Brönsted酸量基本呈现正向关联. 通过间二甲苯歧化反应预积 碳堵塞超笼及碱性探针分子2,4-二甲基喹啉吸附覆盖表面半超笼的方法, 研究CTAB修饰前后各样品的不同孔道系统对酰基化反 应的催化贡献. 结果表明, 酰基化反应主要发生在MCM-49分子篎的表面半超笼, 其次为超笼, 正弦孔道的贡献很小. 另外, CTAB 修饰后样品催化活性的提高主要来自于不含 HMI的孔道系统的贡献, 进一步验证在CTAB处理过程中, 改性作用主要发生在 MCM-49分子笁中不含HMI的区域. 结合表征和反应评价结果, 提高酰基化反应活性需尽可能提高催化剂的Brönsted酸量, 这是分 子笁催化剂今后改进的一个主要方向.

关键词: MCM-49分子笁; 模板剂; 后处理; 十六烷基三甲基溴化铵; 酰基化

收稿日期: 2015-04-05. 接受日期: 2015-05-05. 出版日期: 2015-10-20.

*通讯联系人. 电话/传真: (0411)84379279; 电子信箱: lyxu@dicp.ac.cn

本文的英文电子版由Elsevier出版社在ScienceDirect上出版(http://www.sciencedirect.com/science/journal/18722067). 